Anita Gulczyńska

https://doi.org/10.26881/pwe.2020.50.05

ORCID: 0000-0002-9742-8438

Uniwersytet Łódzki

anita.gulczynska@uni.lodz.pl

Monika Wiśniewska-Kin

ORCID: 0000-0002-6300-8435

Uniwersytet Łódzki

monika.kin@uni.lodz.pl

\title{
Od „wjeżdżania w bramy” do ,otwierania (się) bramy”. Przykład animacji kultury upełnomocniających głos dziecka w procesie rewitalizacji miejskiej
}

\section{Summary}

From "entering the gates" to "opening ourselves up the gates". The example of cultural animations empowering children's' voice in the process of urban revitalization

The subject of our study is the positionality of children in the process of urban revitalization. We understand the city as a learning space. From our point of view changes introduced into that space are always interventions into children's learning processes. In the article we present an empiricallybased reconstruction of practices of community cultural animations that aim at empowering children's voice in the processes of revitalization. Konrad Dworakowski's and Pinokio Theatre's community cultural animations, realised from 2014 to 2019 in Łódź, offer interesting examples of such practices. Even though we build or argument on the basis of observations collected in Łódź, it can be reliably reflected in discussions on educational issues in urban changes in other post-industrial cities.

Keywords: urban revitalization, empowerment, cultural animation, exclusion, inclusion

Słowa kluczowe: rewitalizacja miejska, upełnomocnienie, animacje kultury, ekskluzja, inkluzja

\section{Wprowadzenie}

W tekście podejmujemy kwestię pozycji dziecka w procesach rewitalizacji. Rewitalizacja jest rozumiana jako „proces wyprowadzania ze stanu kryzysowego”, cechujący się „koncentracją negatywnych zjawisk społecznych (bezrobocia, ubóstwa, przestępczości, niskiego poziomu edukacji lub kapitału społecznego, a także niewystarczającego poziomu uczestnictwa w życiu publicznym i kulturalnym)" (Ustawa z dnia 9 października 2015 r. o rewitalizacji, tekst jedn.: Dz. U. z 2020 r., poz. 802, ze zm.). W sposobach planowania 
i organizacji rewitalizacji miejskiej można zauważyć, że na tle rozbudowanych inwestycji koncepcyjnych i kapitałowych refleksja nad warstwą społeczną, w tym edukacyjną, upełnomocniającą głos dziecka, jest niewystarczająca.

Niniejszy artykuł jest próbą uzasadnienia potrzeby zmiany pozycji dziecka w procesach rewitalizacji miejskiej. W tym celu zostały omówione wybrane koncepcje zubożałych sąsiedztw jako miejsc uczących, a także podjęto próbę zrekonstruowania praktyk interwencji w tkankę społeczną miasta. Autorki nie zamierzały wskazywać na jeden obowiązujący sposób myślenia o obecności dziecka w procesie rewitalizacji społecznej. Celem nie było też uogólnienie wyniku badań, lecz jedynie uwypuklenie niektórych z możliwych sensów, wpisanych w przebieg procesu rewitalizacji. Autorki nie dążyły również do weryfikacjj skuteczności projektów animacyjnych. Przeprowadziły natomiast wielokierunkowy, z założenia otwarty sposób analizy, w którym duże znaczenie przypisuje się zorganizowaniu oddolnej inicjatywy, wyzwalającej dziecięcą gotowość do działania, przekraczania barier narzuconych przez rzeczywiste doświadczenia, naoczność życiową.

Geofizyczne granice refleksji przedstawionej w artykule wyznacza kontekst łódzki. Biorąc pod uwagę historyczne i polityczno-ekonomiczne uwarunkowania procesów degradacji materialnej i społecznej obszarów poddawanych rewitalizacji, argumentacja budowana w oparciu o obserwację łódzkich doświadczeń może znaleźć trafne odzwierciedlenie w dyskusji wokół kwestii wychowawczych w zmianach urbanistycznych w innych miastach postindustrialnych.

Miejsca zamieszkania, o których mowa, są identyfikowane przez następujące terminy: „enklawy biedy” (Grotowska-Leder 1998), „obszary zdegradowane społecznie” (www. sejm.gov.pl) czy „sąsiedztwa/społeczności zubożałe” (Gulczyńska 2013). W artykule autorki przyjęły ostatnie z tych pojęć - objęły nim takie miejsca zamieszkania, które:

- w niewielkim obszarze zbierają wzajemnie znających się mieszkańców, współtworzących w codziennej komunikacji społeczną historię miejsca;

- skupiają w tym obszarze redukujące procesy społeczne zachodzące między mieszkańcami (procesy społecznego uczenia się, więzi społeczne etc.) oraz efekty zachodzących poza tymi miejscami procesów egzogenicznych (np. uwarunkowań historycznych, ekonomiczno-politycznych, ideologicznych czy w końcu - samorządowych, dyskursywnych i instytucjonalnych praktyk stygmatyzacji takich miejsc etc.).

\section{Sąsiedztwa zubożałe jako miejsca uczące}

Społeczne uwarunkowania procesów wychowawczych i edukacyjnych zawsze dokonują się „gdzieś” i mają swoje „miejsce” (Mendel (red.) 2006; Męczkowska 2006) czy szerzej - przestrzeń geograficzno-kulturową (Szkudlarek (red.) 1995; Melosik 1998). Miejsce jest nie tylko „kawałkiem geografii”, ale przede wszystkim „pozwala” na coś, coś „,dopuszcza” i „umożliwia” (Bruner 2006: 163-179). Miejsca coraz wyraziściej mówią o tym, kim jest człowiek, bo nie istnieją bez znaczeń, które człowiek im nadaje (Bauman 1997). 
Wśród nich odnajdujemy te najbardziej znaczące „,miejsca źródłowej orientacji” (Ricoeur 1975), które stanowią istotny element kreacji ludzkich tożsamości, zarówno w wymiarze „tu i teraz”, jak i biograficznym, w którym stają się egzemplifikacjami „pamięciomiejsc” (Theiss, Mendel 2019).

Miejsca te wypełniają się określonymi znaczeniami, a także pozwalają otworzyć się na znaczenia ważne dla dzieci. Uważna obecność pedagoga w różnych praktykach kulturowych zakotwiczonych w miejscu umożliwia mu wniknięcie w dziecięce sposoby uzgadniania znaczeń, konstruowania wiedzy osobistej, systemu wartości (Zwiernik 2009: 420). Proces ich rozpoznawania zwiększa edukacyjny potencjał takich miejsc, stwarza dzieciom szanse na to, aby mogły zdobywać wiedzę i kreować doświadczenia społeczne. Sprzyja diagnozie środowiskowo-instytucjonalnych wymiarów dzieciństwa, a więc tych doświadczeń, które budują kulturę dziecięcą, wynikają z codziennego życia w przestrzeni prywatnej (Smolińska-Theiss, Theiss 2003: 91). Nie godząc się na zastany kształt rzeczywistości, pedagog-animator miejsca może w nie ingerować, by zmienić warunki kontekstualizujące procesy edukacyjne. Jakość oraz logika procesu tej zmiany zależą od tego, jak pedagog rozumie związki sąsiedztwo-edukacja i na jakich warstwach miejsca koncentruje swoją uwagę.

W takim ujęciu zubożałych sąsiedztw jako miejsc edukacji można odczytać pewne ukryte założenia. Wynikają one z przypisania rodzinom i społeczności lokalnej (sąsiedzkim światom społecznym) kluczowej odpowiedzialności za sukces szkolny (Edwards i in. 2008). Obraz społeczności lokalnej zostaje zredukowany do cech zbiorowości ludzkiej o niskim kapitale społecznym i kulturowym, które stanowią źródło barier w karierze szkolnej. Dziecko w roli ucznia jest postrzegane jako podmiot podatny na złe wpływy sąsiedztwa. Znane są praktyki służące pozbywaniu się uczniów ze szkół, szczególnie dzieci z problemami społecznymi i edukacyjnymi (Delgado-Gaitan 1988; Wehlage i in. 1989; Gulczyńska 2013). Negatywne, skoncentrowane na brakach wzory interpretacji uczniów uznawanych w szkołach czy instytucjach pomocowych za biednych kształtują oczekiwania wobec nich, a w konsekwencji decydują o formach dawanego im wsparcia (Nieto 1998; Rolón-Dow 2005).

Równie ważne staje się rozpoznanie zubożałych sąsiedztw jako miejsc, w których mieszkańcy doświadczają nierówności społecznych, czyli ,sytuacji, w których ludzie są nierówni, ale nie z racji cech cielesnych czy psychicznych, lecz z powodu ich przynależności do różnych grup albo zajmowania różnych pozycji społecznych" (Sztompka 2002: 332). Bycie mieszkańcem takich sąsiedztw powoduje obniżenie szans życiowych. Dzieciom z zubożałych sąsiedztw nadaje się znaczenie „,podmiotów narażonych na strukturalne nadużycia”, których ani oni, ani inni członkowie społeczności nie są świadomi. Powierzchowna znajomość faktycznych warunków jakości ich życia może doprowadzać do ograniczenia ich możliwości, gdyż wyobrażenia, jakie pracownicy instytucji mają na temat dzieci z takich miejsc, wpływają nie tylko na sposób myślenia o nich, o ich warunkach życia i potrzebach, ale również sposób wyrażenia tego, co uważają za możliwe dla nich w przebiegu ich życia. Każde z przedstawionych ujęć zubożałego sąsiedztwa daje odmienne przesłanki do orientowania działania w procesach ich rewitalizacji społecznej. 


\section{Sąsiedztwa zubożałe jako miejsca uczące w procesach rewitalizacji społecznej}

Ujęcie zubożałego sąsiedztwa jako środowiska sprzyjającego negatywnej socjalizacji legitymizuje rozumienie rewitalizacji jako procesu prowadzącego do zmiany znaczenia społeczności w życiu młodego pokolenia. Zmierza ona do zminimalizowania roli lokalnych światów społecznych na rzecz uwypuklenia usług społeczno-edukacyjnych oferowanych w najbliższym otoczeniu. Rewitalizacja społeczna może być wówczas sprowadzana do zmian wzbogacających otoczenie w infrastrukturę sprzyjającą rozciągnięciu kontroli instytucji na sfery dziecięcego życia pozaszkolnego, u podstaw których leżałaby idea edukacjonalizacji. Jej realizacji służą systemowe działania, które prowadzą do rozwoju w najbliższym otoczeniu kompleksowego zaplecza instytucji wsparcia. $Z$ badań wynika, że głównym źródłem są lokalne szkoły oraz świetlice, które często egzemplifikują kategorię „,szkół po szkole”, gdzie główny akcent kładziony jest na kompensację wyników w nauce. Zwyczajowe praktyki wspierania dzieci w uczestnictwie w kulturze ograniczają się do organizowania okoliczności występowania dzieci w roli „odbiorców kultury wyższej”, natomiast jakość ich uczestnictwa w roli jej twórców często zależy od jakości kompetencji twórczych pedagogów (od ich kultury i sposobów organizowania procesu poznawania sztuki zależy, co uczeń wyczyta z wydarzeń, w których uczestniczy).

Na podstawie obserwacji zmian rewitalizacyjnych w Łodzi autorki zauważają, że będące ich częścią interwencje w tkankę społeczną zubożałych sąsiedztw, dokonywane dzięki wielkim funduszom europejskim dyscyplinującym działania ze względu na narzucony czas, z jednej strony sprzyjają imponującemu tempu i zasięgowi zmian urbanistycznych, z drugiej zaś obniżają zainteresowanie wprowadzeniem zmian, które są czasochłonne i trudno identyfikowalne. Być może z tych powodów w przebiegu rewitalizacji społecznej silnie akcentuje się wyposażanie obszarów uznanych za kryzysowe w nowe instytucje społeczno-edukacyjne, czasami bez zaangażowanej współpracy z już istniejącymi placówkami, oraz akcje społeczne mające zmobilizować społeczność na czas realizacji inwestycji (Gulczyńska, Granosik 2016).

W przekonaniu autorek zmiany rewitalizacyjne osadzone w koncepcji zubożałego sąsiedztwa jako miejsca nierówności nie opierają się na instytucjach, gdyż zgodnie z logiką tej koncepcji instytucje są jednym z narzędzi stabilizujących status quo krzywdzący ich mieszkańców. Opowiadamy się zatem za zmianami rewitalizacyjnymi o charakterze oddolnym. Opierają się one na odkrywaniu historyczno-politycznych źródeł warunków życia mieszkańców, aktywizowaniu do działań znoszących zewnętrzne bariery oraz wspieraniu zaangażowania mieszkańców zarówno w procesy diagnozy, jak i opracowanie projektu pożądanych zmian. W literaturze pedagogicznej można odnaleźć inspiracje dla podjęcia w środowisku otwartym pracy skoncentrowanej wokół „wprowadzenia określonych zmian, odbudowy pożądanych wartości, struktur funkcjonujących w przeszłości, (...) przywrócenia do życia, sprawności w przestrzeni ludzkiej egzystencji” (Wilk 2010: 8).

W kontekście tych rozważań ważny jest rozwój namysłu nad rewitalizacją rozumianą jako proces upełnomocnienia mieszkańców zubożałych sąsiedztw w mieście. Upełno- 
mocnienie rozumiane jest jako, ,umocnienie i przywrócenie możliwie pełnej partycypacji jednostek, grup i społeczności, które na skutek różnych procesów historyczno-społeczno-biograficznych zostały zmarginalizowane, zaniedbane czy wykluczone" (Gulczyńska, Granosik (red.) 2014: 16). W taki sposób otwiera się przestrzeń sprzyjająca kulturowej hybrydyzacji przestrzeni edukacji (Szkudlarek 1999). Obie strony tego procesu mają szanse na uwrażliwiającą zmianę, gdyż zawieszeniu ulec mogą wzajemne oceny oparte na powierzchownej wiedzy o ,innym”.

Przytoczona argumentacja każe skupić uwagę nad możliwościami inicjowania projektów upełnomocniających głos dziecka. Ciekawych rozwiązań w tym zakresie dostarczają praktyki uważniające doświadczenia życiowe dzieci za pośrednictwem przekazu artystycznego Konrada Dworakowskiego i Teatru „Pinokio”, prowadzone w latach 2014-2019.

\section{Praktyki upełnomocniania glosu dzieci z zubożałych sąsiedztw. Przykład działań Konrada Dworkowskiego i Teatru „Pinokio” w Lodzi}

Kierowany przez Konrada Dworakowskiego ${ }^{1}$ Teatr Lalki i Aktora „Pinokio” w Łodzi znacznie wykraczał poza ramy tradycyjnej instytucji kultury. Oprócz spektakli repertuarowych, głównie dla dzieci i młodzieży, Dworakowski podejmował działania z pogranicza różnych dziedzin twórczości, ale też edukacji kulturalnej (,Spójrz pod innym kątem”, „Włącz teatr”). Promował i popularyzował sztukę teatru offowego („,Teatralna Karuzela" krążyła wokół najciekawszych polskich i europejskich wydarzeń w sztuce współczesnej dla dzieci i młodzieży) i czynił ją dostępną w przestrzeniach o utrudnionym dostępie do kultury („Teatr pod chmurką"). Widzowie, poznając teatr „od kuchni”, mieli możliwość wspólnego obcowania ze sztuką („Dotknij Teatru”). Dworakowski inicjował też systemowe działania w zakresie rewitalizacji społeczno-kulturowej na terenie Łodzi („Punkty Kultury”, „Domy Kultury”, „Wjeżdżamy w bramy”, „Tu mówi miasto” i „,Wołanie miasta”). Z przenikliwej diagnozy Dworakowskiego wynika, że: „granie w Śródmieściu jest pewnym komunikatem - historia nie musi kończyć się na śmierci tego miejsca. Najpierw musimy mieć pomysł na własne odrodzenie w tym wszystkim" (Dworakowski 2019).

Zaprojektowane działania sprzyjały odzyskiwaniu szacunku i nabywaniu nowej tożsamości przez uczestników lokalnych światów społecznych: „Nie chcieliśmy przychodzić do mieszkańców Łodzi z »kulturką«, ale raczej poprosić ich o zaproszenie w swoją przestrzeń, by wyszli ze swoimi krzesłami, częstowali się herbatą i opowiedzieli nam o sobie" (Kazimierczak 2015). Oswajanie z dorosłymi, a przede wszystkim z dziećmi

\footnotetext{
1 Konrad Dworakowski, reżyser i aktor, absolwent i wykładowca białostockiego Wydziału Sztuki Lalkarskiej Akademii Teatralnej im. Aleksandra Zelwerowicza w Warszawie. Kierownik artystyczny Teatru Lalek Guliwer w Warszawie (2003-2005), dyrektor naczelny i artystyczny Teatru Lalki i Aktora „Pinokio" w Łodzi (2009-2019). Reżyserował w teatrach lalkowych i dramatycznych w Polsce oraz za granicą. Najważniejsze produkcje: Mikrokosmos Teatru Pantomimy we Wrocławiu, Balladyny i romanse, Bruno Schulz - historia występnej wyobraźni, Chłopcy z Placu Broni oraz Dumanowski side A. Konrad Dworakowski jest autorem scenariuszy i tekstów piosenek; pisze zarówno dla dzieci, jak i dla dorosłych. Prowadzi także autorskie warsztaty z teatru formy. Zob. www.bok.lodz.pl, 17.02.2020.
} 
z zubożałych sąsiedztw dokonywało się w procesie nadawania miejscu znaczeń opisywanych i odczuwanych zarówno przez uczestników, jak i inicjatorów zmiany: „(..) język musi się zmieniać. Myśmy pierwszy projekt robili, »wjeżdżając w bramy«, czyli krótko mówiąc, my wpadamy do was, otwieramy wam bramę i pokazujemy sztukę. Z czasem »wjeżdżanie« zastąpiliśmy »otwieraniem«. Pojawiły się pytania: »Kto może otworzyć bramę? Kim jest gospodarz? « Otwieranie bramy było zaangażowaniem mieszkańców w te sytuacje" (Dworakowski 2019).

Z czasem zasięg „migotania znaczeń” (Melosik, Szkudlarek 1998) się rozszerzał. Sprowadzał się do tworzenia warunków do bycia wspólnotowego, dorastania do poszanowania odrębności: „,...) więcej zrozumieliśmy dopiero po tych pierwszych projektach. Na początku wydawało nam się, że my wchodzimy z jakimś dobrem, z kulturą, której mieszkańcy nie mają, więc to my ją damy. $Z$ czasem, kiedy zaczęliśmy zadawać pytania, zrozumieliśmy, że nasze wyobrażenia o tym, że my mamy coś lepszego, jest po prostu nie fair, i że nie zbudujemy tam jakości, że my po prostu musimy przede wszystkim ich poznać i zrozumieć" (Dworakowski 2019).

Pomysł Dworakowskiego na współtworzenie teatru na kanwie doświadczeń życiowych mieszkańców, z szacunkiem do ich języka i przeżyć, kompetencji twórczych i zaangażowania, wpisuje się w koncepcję edukacji „nawołującej do osadzenia edukacyjnego doświadczenia podmiotu w przestrzeni różnicy, która dostarcza mu możliwości pokonywania granic pomiędzy odmiennymi obszarami kultury” (Męczkowska 2006: 48). Obie strony tak rozumianego procesu edukacji przechodzą przemianę, która polega na zawieszeniu wzajemnych ocen opartych na powierzchownej wiedzy o ,innym”.

Wrażliwość Dworakowskiego na subtelne związki między miejscem, interwencjami edukacyjnymi w miejsce a tym, czego jego młodzi mieszkańcy uczą się o samych sobie, wyznacza cele projektów. Praktyki sprzyjające pogłębianiu relacji i więzi spolecznych w miejscu zamieszkania oraz postrzeganiu trudnych edukacyjnie, słabo umotywowanych podmiotów w roli wspóltwórców kultury zdradzają orientacje oparte na sile u ich pomyslodawców już na etapie konceptualizacji. W przedstawianych w niniejszym artykule projektach Dworakowskiego można odczytać przykłady projektów prac społecznych wyprowadzonych ze sztuki, które intuicyjnie wręcz egzemplifikują praktyki zwiększające włączenie edukacyjne dzieci z zubożałych sąsiedztw. Zostały uporządkowane w trzy kategorie projektów animacyjnych, wzmacniających włączenie edukacyjne dzieci w wyniku: 1) udostępniania uczestnictwa w kulturze; 2) redukowania procesów stygmatyzacji oraz 3) uważniania głosu mieszkańców.

W obszarze pierwszym mieszczą się dwa projekty: „Punkty Kultury” i „Domy Kultury”2. Biorąc pod uwagę ich fizyczną lokalizację - w sąsiedztwie, w domach mieszkańców oraz w domach - placówkach, tj. domu samotnej matki, domu dziecka, domu pomocy

2 Literacką inspiracją projektów jest Miron Białoszewski - polski poeta, prozaik, dramatopisarz i aktor teatralny, w swoich utworach nieustannie postulujący bliską, intymną rozmowę z czytelnikami i słuchaczami. Twórca Teatrów na Tarczyńskiej oraz Teatru Osobnego funkcjonujących w prywatnych mieszkaniach. Zob. https://www.teatrpinokio.pl/projekty/, 17.02.2020. 
społecznej, odwrócona została relacja władzy w relacji człowiek-kultura. Profesjonalni artyści stali się fizycznie gośćmi mieszkańców. Zachęcając do wspólnego bycia, nie uzależniali go od dostępności biletów, decyzji instytucji edukacyjnych, które proponują uczniom „wyjście do teatru”. Łącznikami między teatrem i mieszkańcami byli opiekunowie grup, mający kompetencje pedagogów ulicy. Wydarzenie kończył piknik rewitalizacyjny, w którego program wchodziły prezentacje artystycznej pracy uczestników oraz plenerowe spektakle i koncerty teatru, np. w Wozie Metafizycznym, czyli mobilnej scenie Teatru „Pinokio” (https://www.teatrpinokio.pl/projekty). „Punkty Kultury” wydają się odpowiadać na potrzeby upełnomocniającej redefinicji dzieci, przebiegającej w ścisłym związku z procesami rewitalizacji.

Założenie udostępniania uczestnictwa w kulturze przenika też projekt „Dialogus de Passione \# Pasja Dialogu"3, który egzemplifikuje praktykę redefinicji tożsamości całych społeczności. Wydarzenie to zainicjowało dyskusję o filozofii „spotkania” według Józefa Tischnera, Martina Bubera oraz Emmanuela Levinasa. Korespondująca z ich treścią wystawiona w Wielki Piątek droga krzyżowa posłużyła za przykład spotkania z Najwyższym, z drugim człowiekiem (twarzą w twarz) oraz z innym i sobą w relacji „Ja-Ty” oraz „Ja-Ono”. Spektakl miał charakter plenerowy: rozgrywał się w zdegradowanej dzielnicy Łodzi między ulicami Włókienniczą i Jaracza (ich mieszkańcy, reprezentujący różne grupy wiekowe, naturalnie stali się współuczestnikami wydarzeń, towarzyszyli pochodowi pasyjnemu). Punkt kulminacyjny spektaklu wyostrzył znaczenie Pasji Dialogu. „Droga krzyżowa była u nas niemal kompletnie oczyszczona z interpretacji, szukaliśmy raczej fabularnego przebiegu i znaków wizualnych, aby widz mógł sam budować własne obrazy, asocjacje, rozwiązania. Nie wykorzystaliśmy prawie żadnych tekstów, posługiwaliśmy się intermediami, by skontrapunktować te wydarzenia, pojawiały się również pieśni pasyjne, które wprowadzały treść emocjonalną, duchową i uruchamiały konteksty liturgiczne, choć nie stanowiły tu głównej opowieści. Sensem była po prostu droga, którą aktorzy przeszli wraz z widzami. Ważnym zabiegiem było też to, że nie pojawił się w naszej Pasji krzyż, tylko wielki stół, który ciągnął za sobą Chrystus. Dało się zauważyć ogromne, narastające skupienie wśród uczestników. Pojawiając się w tej dość nieprzyjaznej dzielnicy, naturalnie budziliśmy początkowo mnóstwo komentarzy, natomiast piękna była cisza, która powstała pod koniec. Ona powiedziała nam bardzo dużo. Skupienie, w którym ludzie pozostawali przez dobry kwadrans, patrząc na płonące Oko Opatrzności - to wszystko zadziałało zgodnie z naszą intuicją, że pewne instynkty pierwotne odgrywają znaczącą rolę w percepcji takiego zdarzenia. Poza muzyką i ogniem, najsilniejszym bodźcem była sama droga" (Dworakowski 2019).

Zasadniczym aspektem podejmowanych działań było więc wydobywanie z kulturowego nie-bycia grup pozbawionych możliwości sprawczych przez uruchomienie gotowości do odbudowy własnego statusu. W ten sposób Dworakowski łączy dwa uzupełniające

\footnotetext{
3 Wśród twórców zdarzenia znaleźli się: Teatr Chorea z jego założycielem Tomaszem Rodowiczem, Teatr Szwalnia z Ewą Łukasiewicz, Pracownia Fizyczna Jacka Owczarka, Grupa KIJO z Michałem Ratajskim, Carnival Otwarta Przestrzeń Cyrkowa oraz Teatr Ognia i Papieru Grzegorza Kwiecińskiego.
} 
się procesy: upełnomocniającą redefinicję tożsamości uczestników działań artystycznych z redefinicją ich „miejsca”. Takie działania artystyczne zmierzają do równoważenia społecznego wizerunku mieszkańców, gdyż ujawniają ich gotowość do aktywnego uczestnictwa w tworzeniu kultury.

Inny projekt „Wjeżdżamy w bramy” pozwala zrekonstruować pewne cechy kontekstu tych projektów, które zwiększają potencjał edukacyjnej inkluzywności przez redukowanie procesów stygmatyzacji dzieci i ich sąsiedzkich światów społecznych (obszar drugi). Częściowo improwizowane, częściowo muzyczne przedstawienie zachęcało najmłodszych uczestników podwórek do refleksji nad otaczającą ich rzeczywistością przez aktywny udział w spektaklu, pełniącym funkcję oczyszczającą i integracyjną. Prezentowany w łódzkich dzielnicach projekt stworzył przestrzeń do myślenia o znaczeniu życia w sąsiedztwie, wyrażonego w tekście piosenki Pozwólmy dziecku żyć po sqasiedzku. Dostarczył inspiracji, jak upełnomocnić głos młodych pokoleń zubożałych sąsiedztw i jak uczynić go sprawczym. W spektaklu ,(...) nie mówi się ponad głowami uczestników - wyłącznie do uprzywilejowanych grup. Uczestnicy zostają zaproszeni do współtworzenia sensów i znaczeń, do dzielenia się swoimi wspomnieniami, przeżyciami, doświadczeniami, które w jakiś sposób ich określają, do konfrontowania się z pytaniami: jak to jest u was, jak wygląda wasz świat?" (Dworakowski 2019).

W kolejnych projektach „Tu mówi miasto” i „Wołanie miasta” Dworakowski zaprasza dzieci i ich opiekunów w roli „ekspertów z doświadczenia” do współtworzenia spektakli opowiadających o znaczeniu sąsiedztwa w ich życiu (obszar trzeci). Mieszkańcy zaniedbanych zakątków Łodzi rozpoznawali, jaką wartość ma słowo i jaka jest jego twórcza moc. W wyniku działań artystyczno-edukacyjnych została stworzona płaszczyzna komunikacji dzięki wykreowaniu wspólnego języka miasta, złożonego z głosów z poszczególnych dzielnic Łodzi. Celem współtworzenia tego głosu było wykreowanie okoliczności do jego publicznego wystawienia w łódzkich dzielnicach oraz wydobywanie z kulturowego i społecznego nie-bycia w dyskursie miejskim grup pozbawionych możliwości sprawczych.

W efekcie projektów zmierzających do uważniania głosu dzieci ujawnia się ich gotowość do współtworzenia kultury i to w oparciu o treści bliskie ich doświadczeniom życiowym. Pochodzące od uczestników znaczenia uwiarygadniają współtworzone narracje, ponieważ z jednej strony są one usytuowane lokalnie „blisko problemu”, z drugiej zaś powtarzają się w kilku sąsiedztwach. Wydają się rozbudowywać praktykę poszerzenia dyskursu miejskiego i publicznego o narracje wykluczonych z pewnych przywilejów obywateli. „Wołanie miasta” nie jest już głosem jednego sąsiedztwa, lecz kilku. Głosy te, wspólnie przemawiając, stają się swoistego rodzaju oddolnie budowaną narracją miejsc i ludzi, którzy na przestrzeni dziejów miasta byli nierówno traktowani w doświadczaniu skutków historycznych i polityczno-ekonomicznych zmian, bez możliwości zabierania głosu w zmianach miasta.

W tych aktach refleksji nad znaczeniem miejsca w życiu jego uczestników, współtworzonych w dialogu z osobami z zewnątrz, można rozpoznać praktykę podnoszenia świadomości mieszkańców (Payne 1991). Uświadamianie (Payne 1991) obejmuje proces 
refleksji nad charakterem struktur społecznych i wypracowanie alternatywnego obrazu rzeczywistości, oferującego odmienny sposób definiowania problemów społecznych. W historiach opowiadanych przez dzieci pojawiały się bowiem przykłady trudności, świadczących o zaniedbywaniu ich potrzeb przez podmioty decyzyjne w mieście, jak np. ograniczanie na podwórkach miejsc ich spontanicznej zabawy na rzecz miejsc parkingowych i dyscyplinowanie lokalnych grup rówieśniczych, kiedy te opierały się symbolicznemu wyrzucaniu ich z podwórek i „przekazywaniu” ich pod „nadzór” lokalnych władz oświatowych.

Zaproponowana przez Dworakowskiego zmiana dotycząca uczestnictwa w kulturze mieszkańców zubożałych sąsiedztw ma charakter jakościowy. Po pierwsze w nawiązaniu relacji z kulturą biorą udział profesjonalni artyści, a nie nauczyciele czy wychowawcy. Po drugie w tej nowej relacji rola mieszkańców ewoluuje z odbiorców kultury w jej współtwórców, co wyraża się nie tylko w przyjmowaniu roli aktorów, organizatorów przedstawienia, ale także uznania ich doświadczeń życiowych za istotną treść spektakli, a ich samych za zdolnych do nadania im formy artystycznego wyrazu. Szczególnie ten wątek wybrzmiewa w myśli Mirona Białoszewskiego: ,żeby robić literaturę, nie należy nigdy sięgać do literatury. Trzeba ją robić z czegoś żywszego i innego, właśnie z życia. Z życia i przeżycia" (Białoszewski 2003: 10). Po trzecie możliwe staje się doświadczenie relacji z kulturą jako procesem, w którym uczestnictwo jest wyborem samych mieszkańców, a nie jednorazowym, często odgórnie narzuconym wydarzeniem.

Przywołana jakościowa strategia działania wyzwala skojarzenia z procesem nazwanym w modelu radykalnej pracy społecznej „kolektywizacją” (Payne 1991). Polega ona na zwiększaniu siły oddolnie tworzonego głosu grup marginalizowanych poprzez łączenie sił i zwiększanie społecznej wiarygodności i reprezentacji w zmianach istotnie ich dotyczących. Zwiększa to nacisk na decydentów i możliwości przyjęcia przez nich innej perspektywy dotyczącej zmian w mieście, w tym w procesach rewitalizacji. Postrzegając mieszkańców w roli współtwórców kultury, uwydatnia bliską im, nie instytucjom, definicję ich samych oraz ich światów społecznych. Umożliwia lepsze wzajemne poznanie się, sprzyjające zrozumieniu odmiennej perspektywy, tworzy okoliczności do zatrzymania się, zaciekawienia ,innym”, do rozwoju uwrażliwionego spojrzenia na rozumienie odmiennej perspektywy, sprowokowanego uczenia się siebie nawzajem, wypracowywania przekładalności perspektyw oraz umiejętności negocjacji między podmiotami reprezentującymi odmienne, nierzadko znoszące się ujęcia rzeczywistości, a także sprzyja otwarciu na budowanie czegoś nowego, wspólnego, ponad podziałami (Gulczyńska, Granosik (red.) 2014: 157).

Zaprezentowane rozważania uświadamiają nowe możliwości. Animacje kultury ewoluujące z „wjeżdżania w bramy” w kierunku „otwierania (się) bramy” oferują oryginalne przykłady, jak może być realizowany postulat upełnomocnienia głosu dziecka w procesie rewitalizacji miejskiej. Rozważania te wskazują również kierunek dalszych poszukiwań. 


\section{Literatura}

Bauman Z. (1997), O turystach i włóczęgach, czyli bohaterach i ofiarach ponowoczesności. W: J.P. Hudzik, J. Mizińska (red.), Pamięć, miejsce, obecność. Wspótczesne refleksje nad kultura i ich implikacje pedagogiczne. Lublin, Wydawnictwo Uniwersytetu Marii Curie-Skłodowskiej.

Białoszewski M. (2003), Mówienie o pisaniu. W: tegoż, Wiersze. Wybór. Warszawa, PIW.

Bruner J. (2006), Kultura edukacji. Kraków, Universitas.

Delgado-Gaitan C. (1988), The Value of Conformity: Learning to Stay in School. „Anthropology and Education Quarterly", 19(4).

Dworakowski K. (2019), Od „, wjeżdżania w bramy” do „otwierania się na bramy”. Przykłady projektów uobecnionych w przestrzeni miejskiej. Nieopublikowany wywiad z K. Dworakowskim, przeprowadzony przez A. Gulczyńską i M. Wiśniewską-Kin, 5.10.2019.

Edwards C.P., Sheridan S.M., Knoche L. (2008), Parent Engagement and School Readiness: Parent-Child Relationships in Early Learning. „Faculty Publications, Department of Child, Youth, and Family Studies", 60. https://digitalcommons.unl.edu/cgi/viewcontent.cgi?article=1060\&co ntext=famconfacpub, 18.06.2015.

Grotowska-Leder J. (1998), Łódzkie enklawy biedy. W: W. Warzywoda-Kruszyńska (red.), Żyć i pracować w enklawach biedy. (Klimaty tódzkie). Łódź, Instytut Socjologii Uniwersytetu Łódzkiego.

Gulczyńska A. (2013), „Chłopaki z dzielnicy”. Studium społeczno-pedagogiczne z perspektywy interakcyjnej. Łódź, Wydawnictwo Uniwersytetu Łódzkiego.

Gulczyńska A., Granosik M. (red.) (2014), Empowerment w pracy socjalnej: praktyka i badania partycypacyjne. Warszawa, WYG International.

Gulczyńska A. Granosik M. (2016), Rewitalizacja w perspektywie społeczno-pedagogicznej. W: A. Żukiewicz (red.), Pedagog społeczny. Teoria i praktyka działalności społecznej. Łódź, Wydawnictwo Uniwersytetu Łódzkiego

Kaźmierczak S. (2015), Otwierać bramy. http://www.teatr-pismo.pl/ludzie/1140/otwierac_bramy/, 18.06.2015.

Melosik Z. (1998), Obywatelstwo, czas (historia) i przestrzeń (geografia). W: Z. Melosik, K. Przyszczypkowski (red.), Wychowanie obywatelskie. Studium teoretyczne, porównawcze, empiryczne. Poznań-Toruń, Edytor.

Melosik Z., Szkudlarek T. (1998), Kultura, tożsamość i edukacja. Migotanie znaczeń. Kraków, Oficyna Wydawnicza „Impuls”.

Mendel M. (red.) (2006), Pedagogika miejsca. Wrocław, Wydawnictwo Naukowe Dolnośląskiej Szkoły Wyższej.

Męczkowska A. (2006), Locus educandi. Wokót problematyki miejsca w refleksji pedagogicznej. W: M. Mendel (red.), Pedagogika miejsca. Wrocław, Wydawnictwo Naukowe Dolnośląskiej Szkoły Wyższej.

Nieto S. (1998), Fact and fiction: Stories of Puerto Ricans in U.S. schools. „Harvard Educational Review", 68.

Payne M. (1991), Modern Social Work Theory. London, Palgrave Macmillan Press Ltd.

Ricoeur P. (1975), Egzystencja i hermeneutyka: rozprawy o metodzie. Warszawa, Instytut Wydawniczy PAX.

Rolón-Dow R. (2005), Critical Care: A Color (full) Analysis of Care Narratives in the Schooling Experiences of Puerto Rican Girls. „American Educational Research Journal Spring”, 42(1). 
Smolińska-Theiss B., Theiss W. (2003), Stulecie dziecka: między mitem a zniewoleniem. W: J. Wilk (red.), W stużbie dziecku - blaski i cienie. Lublin, Katolicki Uniwersytet Lubelski.

Szkudlarek T. (1999), Media. Szkic z filozofii i pedagogiki dystansu. Kraków, Oficyna Wydawnicza „Impuls”.

Szkudlarek T. (red.) (1995), Różnica, tożsamość, edukacja: szkice z pogranicza. Kraków, Oficyna Wydawnicza „Impuls”.

Sztompka P. (2002), Socjologia. Kraków, Wydawnictwo Znak.

Theiss W., Mendel M. (2019), Pamięć i miejsce. Perspektywa społeczno-edukacyjna. Gdańsk, Wydawnictwo Uniwersytetu Gdańskiego.

Wehlage G.G., Rutter R.A., Smith G.A., Lesko N., Fernandez R.R. (1989), Reducing the risk: school as communities of support. London, Falmer Press.

Wilk T. (2010), Rewitalizacja społeczna poprzez wspótczesna sztukę teatralna w ocenie reprezentantów (twórców i odbiorców) sztuki dramatycznej Legnicy, Nowej Huty i Wałbrzycha. Katowice, Wydawnictwo Uniwersytetu Śląskiego.

Zwiernik J. (2009), Dziecięca codzienność w przestrzeni podwórka. W: D. Klus-Stańska, M. Szczepska-Pustkowska (red.), Pedagogika wczesnoszkolna - dyskursy, problemy, rozwiązania. Warszawa, Wydawnictwa Akademickie i Profesjonalne. 